\title{
SALIVA ACID PHOSPHATASES AND AMYLASE IN SENOI AND ABORIGINAL MALAYS AND SUPEROXIDE DISMUTASE IN VARIOUS RACIAL GROUPS OF PENINSULAR MALAYSIA
}

\author{
S.G. TAN and Y.S. TENG* \\ Department of Biology, Faculty of Science and Environmental Studies, \\ Universiti Pertanian Malaysia, Serdang, Selangor, Malaysia \\ *University of California ICMR, Institute for Medical Research, Kuala Lumpur, Malaysia
}

\begin{abstract}
Summary Senoi and Aboriginal Malays of Peninsular Malaysia, surveyed for saliva acid phosphatases, amylase and superoxide dismutase, were polymorphic for Sap-A and Sap-B. Senoi were also polymorphic for SOD B. Malays, Chinese and Indians from Malaysia were phenotyped for SOD A and SOD B, using saliva. Though no SOD A variant was detected in any of the three racial groups, Malays and Indians showed rare variants for SOD B.
\end{abstract}

\section{INTRODUCTION}

Malayan aborigines can be divided into three major groups, the Negritos (or Semang) who are nomadic hunters and gatherers and have tightly curled hair, the Senoi who are agriculturalists and have straight to loosely woolly hair, and the Aboriginal Malays who are stoutly built and have dark skin (William-Hunt, 1952). The Negritos, the smallest, least accessible and most primitive group of all, live in the north of Peninsular Malaysia (formerly known as Malaya) and are part of a group that is represented in the Andaman Islands, South Thailand, the Philippines and New Guinea (Sullivan, 1918, 1921). The Senoi, the most numerous of the three groups, live mainly in or near the central hills and mountains of the Malay Peninsula. They may be related to the Veddas of Ceylon and the Australian aborigines (Cole, 1945) or to the Mongoloids (Green, 1949). The Aboriginal Malays live in the south of the peninsula and are similar to the Malays, both groups showing Mongoloid characteristics. There are about 1,820 Negritos, 30,370 Senoi and 20,830 Aboriginal Malays living in the peninsula (Carey, 1976).

The Malayan aborigines are of great interest to anthropologists and population geneticists because they probably are the remnants of a widespread ancient population in Southeast Asia that was driven into the hinterland they now inhabit by 
culturally and technologically more advanced races. Lie-Injo (1976) made a comprehensive review of the blood genetic data on the Malayan aborigines. We report the results of a survey for saliva acid phosphatases, saliva amylase and superoxide dismutases among the Senoi and Aboriginal Malays. We also report the results of our survey for soluble and mitochondrial superoxide dismutase (SOD A and SOD B) among Malays, Chinese and Indians from Malaysia using saliva as source material.

\section{MATERIALS AND METHODS}

Saliva samples from Malayan aborigines were obtained from the staff and patients of the Gombak Hospital for Aborigines in Gombak, Selangor and those from Malays, Chinese and Indians were collected in the metropolitan area of Kuala Lumpur. The saliva samples were processed and concentrated as described by Balakrishnan and Ashton (1974). Samples were phenotyped for saliva acid phosphatases as in Tan and Ashton (1976), for saliva amylase as in Teng et al. (1977) and for superoxide dismutase as in Tan (1977) and Tan and Teng (1977a).

\section{RESULTS AND DISCUSSION}

One hundred and fourteen Senoi and 122 Aboriginal Malays were phenotyped for saliva acid phosphatase A (Sap-A) and saliva acid phosphatase B (Sap-B). The phenotypes observed are presented in Table 1. Gene frequencies for locus Sap-A and locus $S a p-B$ were calculated as in Tan and Ashton (1976) from the phenotypic distributions for Sap-A (Table 2) and Sap-B (Table 3).

In Senoi, the gene frequencies for Sap- $A$ are: $A=0.42 \pm 0.04, A^{\prime}=0.01 \pm 0.01$, $A^{0}=0.57 \pm 0.04$; for $S a p-B, B=0.90 \pm 0.05, B^{1}=0.01 \pm 0.01, B^{0}=0.09 \pm 0.05$. In

Table 1. Sap phenotypes of saliva samples from two major groups of Malayan Aborigines.

\begin{tabular}{llllclll} 
Racial groups & \multicolumn{1}{c}{ Sap phenotypes } & & \\
& $A B$ & $A$ & $A A^{\prime} B$ & $A A^{\prime}$ & $B$ & $A B B^{1}$ & Total \\
Senoi & 72 & 0 & 1 & 1 & 38 & 2 & 114 \\
Aboriginal Malays & 85 & 0 & 0 & 0 & 35 & 2 & 122 \\
\hline
\end{tabular}

Table 2. Sap-A phenotypes of saliva samples from two major groups of Malayan Aborigines.

\begin{tabular}{|c|c|c|c|c|c|c|c|}
\hline \multirow[t]{2}{*}{ Racial groups } & \multicolumn{6}{|c|}{ Sap-A phenotypes } & \multirow[b]{2}{*}{$\mathrm{p}$} \\
\hline & $A$ & $O$ & $A A^{\prime}$ & $A^{\prime}$ & Total & $\chi^{2}$ & \\
\hline Observed & 74 & 38 & 2 & 0 & 114 & 2.78 & $>0.05$ \\
\hline Expected & 74.91 & 37.10 & 0.84 & 1.15 & 114 & & \\
\hline \multicolumn{8}{|c|}{ Aboriginal Malays } \\
\hline Observed & 87 & 35 & 0 & 0 & 122 & & \\
\hline
\end{tabular}


Table 3. Sap-B phenotypes of saliva samples from two major groups of Malayan Aborigines.

\begin{tabular}{llllllll}
\hline Racial groups & \multicolumn{7}{c}{ Sap-B phenotypes } \\
\hline Senoi & $B$ & $O$ & $B B^{1}$ & $B^{1}$ & Total & $\chi^{2}$ & $\mathrm{p}$ \\
$\quad$ Observed & 111 & 1 & 2 & 0 & 114 & 0.22 & $>0.50$ \\
$\quad \begin{array}{l}\text { Expected } \\
\text { Aboriginal Malays }\end{array}$ & 111.10 & 0.90 & 1.85 & 0.19 & 114 & & \\
$\quad \begin{array}{l}\text { Observed } \\
\text { Expected }\end{array}$ & 120 & 0 & 2 & 0 & 122 & 0.01 & $>0.90$ \\
\hline
\end{tabular}

Aboriginal Malays, the gene frequencies for Sap- $A$ are $A=0.46 \pm 0.04, A^{0}=0.54 \pm$ 0.04 ; for Sap $-B, B=0.99 \pm 0.01, B^{1}=0.01 \pm 0.01$.

The observed Sap-A phenotypes for Senoi and the observed Sap-B phenotypes for Senoi and Aboriginal Malays were tested for Hardy-Weinberg equilibrium. The results are shown in Tables 2 and 3, respectively. The number observed for the various phenotypes showed no significant deviation from the number expected.

The gene frequencies observed for the Malayan aborigines are quite similar to those observed for Malays (Tan and Teng, 1977b). In Malays, the gene frequencies for Sap- $A$ are $A=0.47 \pm 0.02, A^{\prime}=0.001 \pm 0.001, A^{0}=0.53 \pm 0.02$; for $\operatorname{Sap}-B, B=$ $0.93 \pm 0.03, B^{0}=0.07 \pm 0.03$.

The presence of the $B^{1}$ allele among the Malayan aborigines is of interest because this allele has only been observed in Chinese and Japanese from Hawaii (Tan, 1975) and in Chinese from Malaysia in whom the $B^{1}$ allele reaches polymorphic proportions (Tan and Teng, 1977b). It has not been detected in Caucasians living in Hawaii and in Indians and Malays in Malaysia. It may be that the $B^{1}$ allele found in the Malayan aborigines originated from the Chinese. According to Dentan (1968) and Carey (1976), Chinese traders and exguerillas from the predominantly Chinese Malayan People's Anti-Japanese Army and later from the outlawed Malayan Communist Party sometimes settled in aboriginal communities and took aboriginal women as wives. There was also a good deal of casual sexual contact between traders and aboriginal women. In addition, during the Japanese occupation of Malaya (1941-1945) and the subsequent Communist insurrection (1948-1960), many Chinese children whose parents were in economic or social distress were adopted by the aborigines. The aborigines then regarded these children as being true aborigines even though they were Chinese.

No saliva amylase variant was detected among 115 Senoi and 111 Aboriginal Malays. This result is not surprising since among the Malays and the Chinese, $\mathrm{Amy}_{1}$ variants occur only rarely (Teng et al., 1977).

Two regions can be observed on superoxide dismutase zymograms of saliva specimens. One region, SOD A, migrates about $6 \mathrm{~cm}$ from the origin toward the anode and corresponds to soluble SOD. The other region, SOD B, migrates about $2.5 \mathrm{~cm}$ anodally and corresponds to mitochondrial SOD (Teng and Tan, 1977). 
Table 4. SOD B phenotypes and gene frequencies among Senoi, Aboriginal Malays, Malays, Chinese and Indians from Malaysia.

\begin{tabular}{lcrrrrr} 
Racial groups & Total & \multicolumn{3}{c}{ Phenotypes } & \multicolumn{2}{c}{ Gene frequency estimates } \\
\cline { 3 - 6 } & & $1-1$ & $2-1$ & $2-2$ & $S O D B^{1}$ & $S O D B^{2}$ \\
\hline Senoi & 123 & 120 & 3 & 0 & 0.988 & 0.012 \\
Aboriginal Malays & 132 & 132 & 0 & 0 & 1.000 & 0 \\
Malays & 288 & 287 & 1 & 0 & 0.998 & 0.002 \\
Chinese & 140 & 140 & 0 & 0 & 1.000 & 0 \\
Indians & 124 & 122 & 2 & 0 & 0.992 & 0.008
\end{tabular}

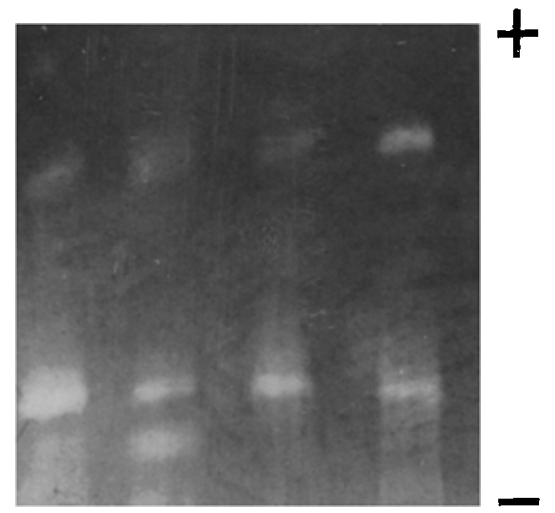

\section{origin}

Fig. 1. Saliva superoxide dismutases

SOD $A$ is further from and SOD B is nearer to the origin. From left to right, channels 1,3 and 4: SOD B 1-1; channel 2: SOD B 2-1. All samples are SOD A 1-1.

Normally each saliva sample shows one intense band in each region. Such bands are coded for by two different loci (Beckman et al., 1973; Shinoda et al., 1974). SOD $A$ is located on chromosome 21 (Tan et al., 1973) and SOD $B$ chromosome 6 (Creagan et al., 1973).

No genetic variant of SOD A was detected among 123 Senoi, 132 Aboriginal Malays, 287 Malays, 122 Indians and 140 Chinese. Teng and Lie-Injo (1977) reported on the absence of variant SOD A in 581 Malays, 435 Chinese and 366 Indians.

The results for SOD B are shown in Table 4. In our system, the normal phenotype SOD B 1-1 usually shows only one intense negatively stained band, but occasionally, with more concentrated specimens, one or more fainter bands may be seen just anodal to the single intense band. These fainter bands are not genetically determined as they are not constant characteristics of an individual (Tan, 1977). The variant phenotype SOD B 2-1 shows two intense bands (Fig. 1), one corresponding to the normal intense band and the other migrating slightly slower than 
the normal band. This variant phenotype was seen three times in Senoi, once in Malay and twice in Indians. Only in Senoi does it constitute a polymorphism.

Shinoda et al. (1974), working with 98 Japanese autopsy liver specimens, detected two individuals showing variation in the SOD B region. They considered them heterozygotes at the $S O D B$ locus. In their starch gel electrophoretic system, the SOD A region migrated anodally much faster than the SOD B region, each region showing one intense band and one weaker band. The two variant individuals reported by Shinoda et al. showed three bands in the SOD B region; one band corresponding to the normal band, one intense variant band which migrated anodally slower than the normal band, and another weaker variant band which migrated anodally the slowest of all three bands. Though the banding patterns are a little different, it is most likely that our SOD B variants are identical to those reported by Shinoda and coworkers.

Acknowledgements This work was supported in part by the University of California ICMR with research grant AI 10051 and by research grant HL 10486, both from the NIH, U.S. Public Health Service and with funds from the Department of Biology, Faculty of Science and Environmental Studies, Universiti Pertanian Malaysia.

We thank Dr. Baharon Azhar bin Raffie'i, Commissioner of the Department of Aborigine Affairs, Malaysia and Dr. Leow Kok Ming, Acting Director of the Gombak Hospital for Aborigines, Gombak, Selangor, for permission to collect saliva samples at the hospital. We also thank Mr. Asaad Khuzami bin Abd. Hamid of the University of California ICMR, Institute for Medical Research, and Mr. Unyah bin Itam of the Gombak Hospital for the collection of saliva specimens.

\section{REFERENCES}

Balakrishnan, C. R. and Ashton, G. C. 1974. Polymorphism of human salivary proteins. Am. J. Hum. Genet. 26: 145-153.

Beckman, G., Lundgren, E., and Tarnvik, A. 1973. Superoxide dismutase isozymes in different human tissues, their genetic control and intracellular localization. Hum. Hered. 23: 338-345.

Carey, I. 1976. Orang Asli: The Aboriginal Tribes of Peninsular Malaysia. Oxford University Press, Kuala Lumpur.

Cole, F. C. 1945. The People of Malaysia. Van Nostrand, New York.

Creagan, R., Tischfield, J., Ricciuti, F., and Ruddle, F. H. 1973. Chromosome assignments of genes in man using mouse-human somatic cell hybrids: mitochondrial superoxide dismutase (indophenol oxidase-B, tetrameric) to chromosome 6. Humangenetik 20: 203-209.

Dentan, R. K. 1968. The Semai: A Nonviolent People of Malay. Holt, Rinehart and Winston, New York.

Green, R. 1949. Anthropological blood groups among the Sakai. Bull. Raffles Museum. Series B 4: $130-132$.

Lie-Injo, L.E. 1976. Genetic relationships of several aboriginal groups in South East Asia. In The Origin of the Australians, edited by Kirk, R. L. and Thorne, A.G. Australian Institute of Aboriginal Studies, Canberra, Australia.

Shinoda, T., Matsunaga, E., and Koshinaga, J. 1974. Polymorphism at a second structural locus for tetrazolium oxidase in Japanese. Jap. J. Hum. Genet. 19: 243-250.

Sullivan, L. R. 1918. Racial types in the Philippine Islands.' Anthropol. Papers of the Amer. Museum. 23: 61 . 
Sullivan, L. R. 1921. A few Andamanese skulls with comparative notes on Negrito craniometry. Anthropol. Papers of the Amer. Museum. 23: 175.

Tan, S. G. 1975. Demonstration on zymograms and genetic studies of some enzymes from human saliva. Ph. D. dissertation, University of Hawaii, Honolulu.

Tan, S. G. 1977. Human saliva superoxide dismutase. Isozyme Bull. 10: 46.

Tan, S. G. and Ashton, G. C. 1976. Saliva acid phosphatases: Genetic studies. Hum. Hered. 26: 81-89.

Tan, S. G. and Teng, Y. S. 1977a. Human saliva as a source of biochemical genetic markers. I. Techniques. Hum. Hered. (in press)

Tan, S. G. and Teng, Y. S. 1977b. Saliva acid phosphatases in Malaysians. Report of a new variant. Hum. Hered. (submitted)

Tan, Y.H., Tischfield, J., and Ruddle, F. H. 1973. The linkage of genes for the human interferoninduced antiviral protein and indophenol oxidase-B traits to chromosome G-21. J. Exp. Med. 137: $317-330$.

Teng, Y. S. and Lie-Injo, L. E. 1977. Erythrocyte superoxide dismutase in different racial groups in Malaysia. A variant in a Filipino. Hum. Genet. 36: 231-234.

Teng, Y. S. and Tan, S. G. 1977. Human saliva as a source of biochemical genetic markers. II. Genetic interpretations and possible utilization. Hum. Hered. (in press)

Teng, Y. S., Tan, S. G., Lopez, C. G., Ng, T., and Lie-Injo, L. E. 1977. Genetic markers in Malaysians: Variants of soluble and mitochondríal glutamic oxalocaetic transaminase and salivary and pancreatic amylase. Phosphoglucomutase III and saliva esterase polymorphisms. Hum. Genet. (in press)

William-Hunt, P. D. R. 1952. An Introduction to the Malayan Aborigines. Government Press, Kuala Lumpur. 